\author{
Enrico RICCHIARDI
}

\title{
Description of eight new species of Dasyvalgus and notes on other Valgina (Coleoptera Cetoniinae Valgina)
}

\begin{abstract}
Riassunto: Descrizione di otto nuove specie di Dasyvalgus e note su altri Valgina.
Lo studio dei Valgina necessita, prima di una revisione generale, di una serie di atti nomenclatori per risolvere le molte incongrunze che derivano dall'accumularsi in più di un secolo di descrizioni di nuove specie. In questo contesto quelle rappresentanti il genere Orientale Dasyvalgus Kolbe presenta particolari problemi per la scarsa variabilità morfologica e per il continuo rinvenimento di ulteriori nuove specie (attualmente 122 , incluse queste nuove otto - e molte altre da descrivere). Questo studio contribuisce a chiarire la situazione con la descrizione di otto nuovi Dasyvalgus, la definizione di due nuovi sinonimi juniori, di un nomen novum e la ridefinizione della distribuzione di una specie.
\end{abstract}

\begin{abstract}
Before a general revision, the study of the Valgina requires a nomenclatural review, in order to resolve the inconsistencies that have resulted from the accumulation of descriptions of new species during the last century. In this context, those representing the Oriental genus Dasyvalgus Kolbe are particularly problematic due to their low morphological variability and the ongoing discovery of new species (currently 122 , - including the eight new here described - and many more to follow). This study aims to clarify the situation with the description of eight new Dasyvalgus species, recognising two new junior synonims, one nomen novum and redefining the distribution of one species.
\end{abstract}

Key words: Coleoptera, Valgina, new species, new synonims, nomen novum, Oriental Region.

\section{INTRODUCTION}

The continuous reporting of undescribed Valgina species from field collections indicates that the diversity of this subtribe in the Oriental Region remains poorly known. Infact, nearly $90 \%$ of loans received for determination from museum and private collections contain new species. Amongst others, the genera Dasyvalgus Kolbe 1904 and Hybovalgus Kolbe 1904, are especially rich in new species, while others such as Oreoderus Burmeister 1842 and Heterovalgus Krikken 1978 are already well known (Ricchiardi 1992, 2001). Consequently, it is not yet possible to undertake a comprehensive revision of the Oriental Valgina at this stage. However, it is necessary to proceed with describing new species and correcting existing nomenclatural problems. It is also important, whenever possible, to describe females of the known species, for the following three reasons:

1. In the genus Dasyvalgus, which comprises more than half of the Oriental Valgina, females are not flower frequenters as are males; subsequently they are collected only occasionally;

2 . The few females of sexually dimorphic species remain undetermined in collections, or have been described as different species or even genera;

3. Description of females in sexually dimorphic species helps to provide better definition of their genera.
As a contribution to a better knowledge of the Oriental Valgina, this work includes the following nomenclatural reviews:

- identification of the type series and description of the female of D. eucharis Kolbe 1904;

- designation of D. polychrous Arrow 1944 as junior synonym of $D$. eucharis;

- description of eight new Dasyvalgus species;

- designation of a nomen novum for D. nigerrimus Miyake 1993;

- designation of a lectotype for Valgus arabicus Nonfried 1895, and placement of that species as a junior synonym of $V$. seticollis Beauvois 1907.

\section{Materials AND Methods}

The total length of a specimen was measured from the anterior margin of the pronotum to the elytral apex; specimen width is the maximum width of elytra. Photos of holotypes were taken with a Nikon Coolpix P6000 fixed to one of the eyepieces of a Wild dissecting microscope. Photos were processed with photo stacking technique, using Combine ZP (Alan Hadley, http:// www. hadleyweb.pwp.blueyonder.co.uk). Finally, backgrounds were removed from photos using Adobe Photoshop, in order to increase clarity of resolution.

The following abbreviations are used in the text to indicate collections where the material examined is currently located. 
MNHUB Museum für Naturkunde, Berlin, Germany.

NHM Natural History Museum, London,UK.

NMER Naturkunde Museum Erfurt, Germany.

SDEI Senckenberg Deutsches Entomologisches Institut (Formerly DEI), Müncheberg, Germany.

SNMS Stuttgart Staatliches Museum fur Naturkunde, Stuttgart, Germany.

ZFMK Zoologisches Forschunginstitut und $\mathrm{Mu}-$ seum Alexander Koening, Bonn, Germany.

USNM United States National Museum Smithsonian Institute, Washington, USA.

WBWC William B. Warner Collection, Chandler, Arizona, USA.

ERC Enrico Ricchiardi Collection, Turin, Italy.

LT Lectotype;

HT Holotype;

PLT Paralectotype;

PT Paratype.

\section{TAXONOMY}

Dasyvalgus eucharis Kolbe, 1904 (Figs. 1,2)

= Dasyvalgus polychrous Arrow, 1944 (new synonim).

TYPE SERIES (here designated). LT $\widehat{\partial}$ (MNHUB), Indonesia, Sumatra, N.O. Sumatra Siboelengit, Jachan legit; 1 PLT $\hat{\alpha}$ (MNHUB), Malaysia, Malacca Perak, Jachan legit; 1 PLT $\hat{\text { ô }}$ (MNHUB), Brunei (Holotype of var. bruneensis Kolbe 1904), Rolle legit.

Other MATERIAL EXAMined. Malaysia: 1 ( NHM), Malaysian Peninsula, Batang Padang, Jor Camp, 29-V1923, 1500 feet, H.M. Pendlebury legit; 1 ㅇ (NHM),

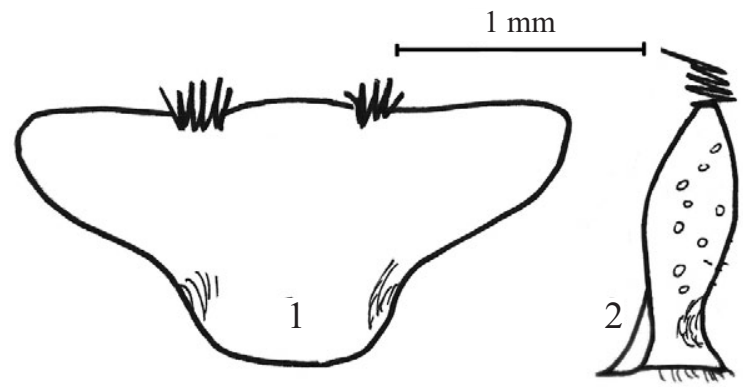

Figs. 1-2. Dasyvalgus eucharis Kolbe (NHM), female pygidium. 1, Frontal and 2, lateral views.
Pahang F.M.S., Lubok Tamang (B.M. 1929-41), 24-VI1923, 3500 feet; 1 ठै (USNM), ex Baker Collection, Malaysia, Sarawak, Sandakan; 3 ô $($ ERC), Mt Goram, 15 km SW Kapit, III-1997, 900 m, TayPooMin legit; 3

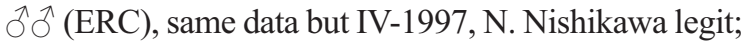
1 ô (ERC), Mt. Bakak, 20 km SW Kapit, IV/V-1997, $1000 \mathrm{~m}$, TayPooMin legit; 2 ô (ERC), Malaysia, Sabah, Ranau, 14-V-2008; Sarawak (LT of D. polychrous Arrow 1904) 1 ठ (NHM, LT), Borneo, W. Sarawak, Mt. Matang, 3000 ft., 20-XII-1913, G.E. Bryant legit. Indonesia: 1 (MNHUB), N.O. Sumatra, Siboelengit; 4 ठぇ (ERC), W. Sumatra, VII-1991; 1 ठ (ERC), W. Sumatra, Singgalang Mt., VII/VIII-1992; 1 $\widehat{\gamma}$ (ERC), W. Sumatra, Payakumbuh (Harau Valley), I1991; 1 Oे (ERC), W. Sumatra, Harau Valley, III-1992, S. Jakl legit; 1 ડ̄ (ERC), Sago Mt., II-1991.

Distribution. This adds the Malaysian Sarakak to the known distribution of D. eucharis (formerly Sumatra, the Malaysian Peninsula and Brunei). As with most Oriental RegionValgini species distribution in Indonesian Borneo is poorly known because of lack of collecting.

Discussion. The type series of D. eucharis (MNHUB) includes three males, two labeled as eucharis and the third as eucharis var. bruneensis. Another species, Dalsyvalgus polychrous Arrow, 1944, is here designated as junior synonim of $D$. eucharis based on it's morphology and parameral shape. As with most Dasyvalgus, the female of $D$. eucharis is undescribed. While studying the NHM Valgini I noticed two females determined as $D$. eucharis by G.J.A, evidently Gilbert John Arrow, who never published a description of them. One is labeled, "Malay Peninsula", and the other "Pahang, F.M.S., Lubok Tamang, 3500 feet, 24 June 1923." I support Arrow's opinion that the two specimens belong to $D$. eucharis. Females of this species are similar to males, but can be distinguished at a glance on the basis of their pygidial shape (Figs. 1,2), which is strongly narrowed at the apex (frontal view) and in lateral view strongly grooved at the apex.

Dasyvalgus pyrrhopygus (Kraatz, 1883) (Figs. 3-6)

TYPE SERIES: Valgus pyrrhopygus. HT $\hat{\sigma}$ (SDEI), Malaysia, Malacca, without any other data.

OTHER MATERIAL EXAMINED. Indonesia: $7 \hat{\jmath}$ (ERC), West Sumatra, VII, 1991; 1 ठ̊ ERC, Sabah, Mt. TrusMadi, 20-II-2005.

Distribution. Sumatra, Malaysian Peninsula, Malacca and Sabah. 


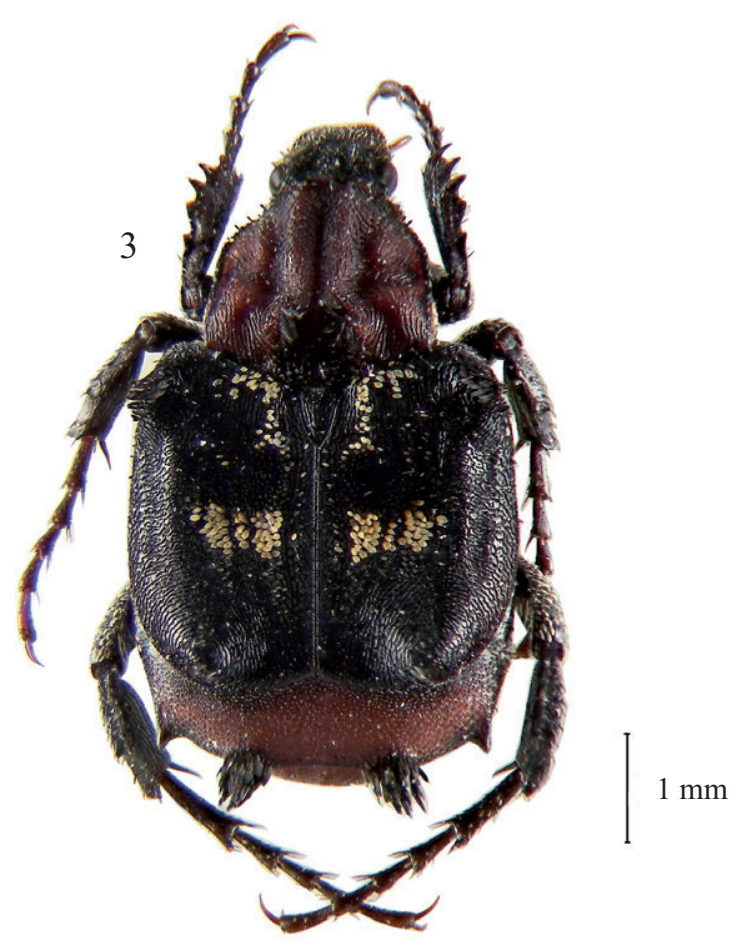

Fig. 3. Dasyvalgus pyrrhopygus (Kraatz, 1883). Male habitus (ERC).

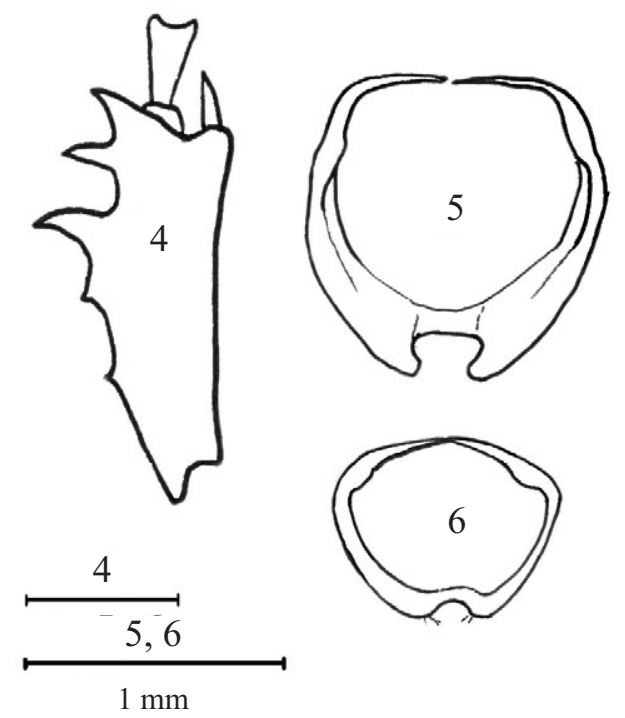

Figs. 4-6. Dasyvalgus eucharis Kolbe, 1904 lectotype male; 4, left protibia; 5, parameres, frontal view. Dasyvalgus pyrrhopygus (Kraatz, 1883) lectotype male; 6, parameres, frontal view.
Kraatz (1883) described this species as part of Valgus citing as "Patria" only Malacca. Kolbe (1904, p. 42) records the following distribution for this species: "Malacca, Sumatra (nach Kraatz); Sumatra (Deyrolle); Birma (von Dr. C.A. Dohrn erhalten; India orient. (erythropygus Dornitzer i.l.) Mus. Berlin". The specimens preserved in the MNHUB collection as "pyrrhopygus" should be the same as those examined by Kolbe and labelled with handwriting. Of the three specimens, two are labelled "Inde Or.;" while the third labelled "Birma" belongs to a different species (Arrow (1944, p. 235) in his "Fauna of British India including Ceylon and Burma" stated: "Dasyvalgus pyrropygus, Kraatz, a Malayan species, has been recorded by Dr. Kolbe from Burma, but as the characters he has assigned do not agree well with those of the type, which I have examined, I have not included it here".

Discussion. The HT shows a brown colored propygidium and pygidium, while in the Sumatran specimens these are black or red. Moreover, the Sumatran and Sabah specimens have the frontal view shape of their parameres identical to that of the HT, but in lateral view their parameres are straight and not arched. The female is unknown.

\section{Dasyvalgus sabahi sp. n. (Figs. 7,8)}

TYPE SERIES. HT $\hat{\partial}$, NHM, Malaysia, Sabah, Mt. TrusMadi, 20-II-2005, local collectors. 8 PT ổ ô: 3 ERC, 3 WBWC, same data as the HT; 1 ERC, 1 WBWC, Malaysia, Sabah, Ranau, May 14, 2008.

HolOtYPE DESCRIPTION. Length $5.8 \mathrm{~mm}$; width 3.7 $\mathrm{mm}$. Body and head black. Head slightly shiny, covered with round, shallow, large, umbilicate puntuation, sometime with testaceous, small, erect scales at center. Clypeus anteriorly sinuate, suctorial brush very long (Longer than the clypeal width). Pronotum slightly shiny; anteriorly narrower; lateral borders sinuate, noticeably crenate; hind angles obtuse; posterior border medially convexly arcuate; carinae parallel, obsolete; lateral and central small carinae obsolete; disc with six scale tufts of erect, long, black scales; two tufts at end of the (obsolete) carinae, four identical tufts close to posterior border, regularly spaced, external two tufts on hind corners. Scutellum short, triangular, longer than wide, slightly rounded at apex, glabrous. Elytra slightly shiny, striae noticeable, covered with recumbent black scales; center of disc with horizontal row of small, erect, white scales, and with rounded spot of 
erect black scales on upper side; intrahumeral and anteapical umbones with noticeable tufts of long, erect, black scales. Propygidium glabrous, slightly shiny, covered with large umbilicate punctures. Tufts of scales on hind border noticeable, black, consisting of long, erect scales. Pygidium slightly shiny, glabrous, covered with same umbilicate punctuation as propygidium; apex rounded, with apical fringe of small, black, erect scales. Protibiae with five external teeth; first three long and pointed, fourth and fifth short, enlarged and pointed. Meso- and metatibiae centrally enlarged, with noticeable central tooth, covered with scattered, long, semi-erect, black scales. First metarsomere approximately 1.5-1.6 times as long as second.

DistRIBUTION. The only known locality is a mountain (Mont Trus-Madi) in Sabah, Malaysia.

REMARKS. There is no noticeable variation within the type series. The female is unknown.

DiAgnosis. This species may be distinguished from two other apparently similar species by its very dis-
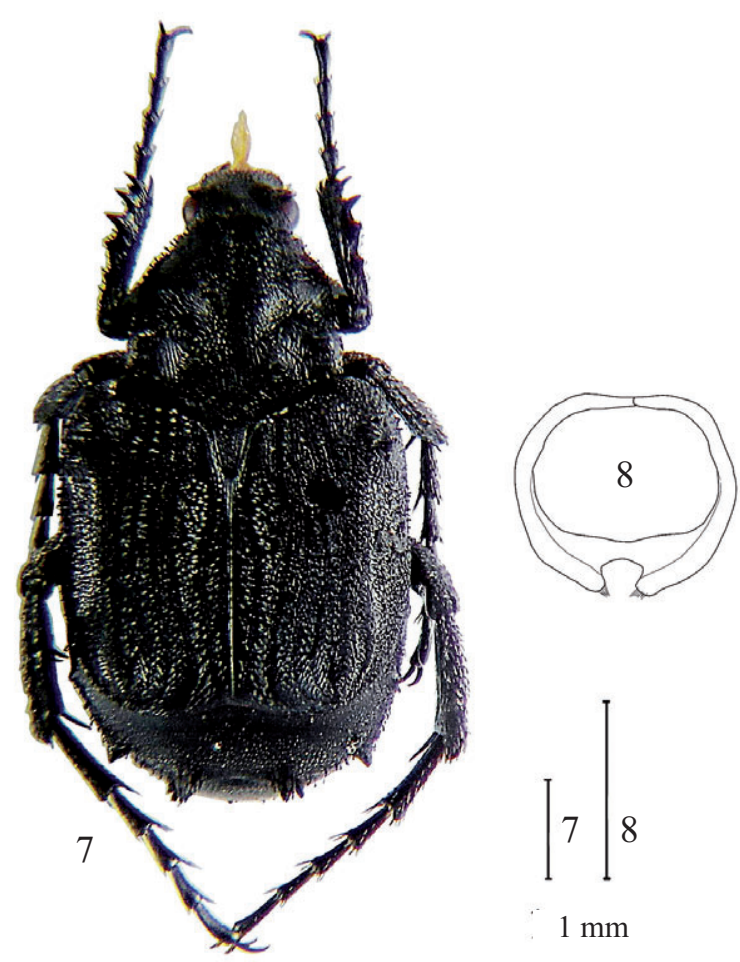

Figs. 7-8. Dasyvalgus sabahi sp.n. holotype male (NHM); 7, habitus; 8 , parameres, frontal view. tinctive parameres, as well as the external characters, as highlighted in the following key.

Key to the males of Dasyvalgus species close to sabahi sp. n.

1. Apex and central longitudinal line of the pygidiun covered with raised, small, circular yellow scales

eucharis Kolbe 1904

Pygidium glabrous .2

2. Elytra with white scales covering a small area behind the center of disk ..........pyrrhopygus (Kraatz 1883)

3. Elitra without white scales in small area behind the center of disc sabahi sp. n.

Dasyvalgus hauseri sp. n. (Figs. 9,10)

TYPE SERIES. HT $\precsim$ SNMS, Malaysia, Sabah, Mt. Kinabalu Park, Poring Hot Springs, 15/30-XII-1995, 500800 m, C. Hauser legit. 1 PT $\widehat{\jmath}$ MNHUB, Sumatra. HOLOTYPE DESCRIPTION. Body. Black. Length $5.2 \mathrm{~mm}$, width $3.2 \mathrm{~mm}$. Head shiny, covered with large, shallow, circular punctures with erect, testaceous setae inside; frons covered with thick, testaceous, recumbent scales that form four small scale tufts in interocular area. Clypeus anteriorly sinuated, suctorial brush very long. Pronotum anteriorly narrower, noticeably crenate at sinuated sides, hind angles obtuse; posterior border centrally curved toward the scutellum; carinae parallel, interrupted after pronotal midpoint by scale tuft which is testaceous anteriorly, blackish posteriorly; base with four blackish tufts, outer two externally testaceous; lateral small carinae obsolete, covered with small testaceous, blackish scale tuft; central small carina obsolete; most of pronotal surface covered with scattered, recumbent testaceous scales. Scutellum short, triangular, slightly rounded at apex, covered with small, recumbent, testaceous scales. Elytra slightly shiny, covered with raised and locally recumbent, small, blackish scales; in juxtascutellar area with anterior band; posterior border covered with testaceous, recumbent small scale forming testaceous, blackish scale tufts on the anteapical umbones; with testaceous tuft on humeral umbones; disc with central rounded small area covered with black, erect, small scales, surrounded by small, testaceous recumbent scales. Propygidium covered with small, testaceous scales, locally recumbent and coffeegrain shaped, or erect and c-shaped; hind border with two noticeable testaceous scale tufts; spiracles elevated, with truncated point. Pygidium slightly laterally compressed close to apex, covered with small, erect, often 
c-shaped, testaceous scales. Disk covered with recumbent, grain-shaped small testaceous scales on lateral and ventral sides, mixed with scales as on other areas. Apex with testaceous tuft of short scale. Protibiae with five external teeth, first and third long and pointed, second small and pointed, fourth and fifth short and rounded. Meso- and metatibiae centrally enlarged, with noticeable central tooth, covered with scattered, small, semierect testaceous scales; first metatarsomere similar in size to second.

REMARKS. The female is unknown.

DiAgnosis. As usual, it is very difficult to define a single character that accurately distinguishes a Dasyvalgus species from congeners, but fortunately the parameres shape is distinctive enough. D. hauseri can furthermore be distinguished by the following combination of characters: colour of the scale tufts; different shape of pygidial scales; shape of the protibial external denticles; relative length of the first and second metatarsal joints.

Distribution. The holotype is from Sabah (North Borneo, Malaysia); the paratype is from Sumatra (Indonesia).
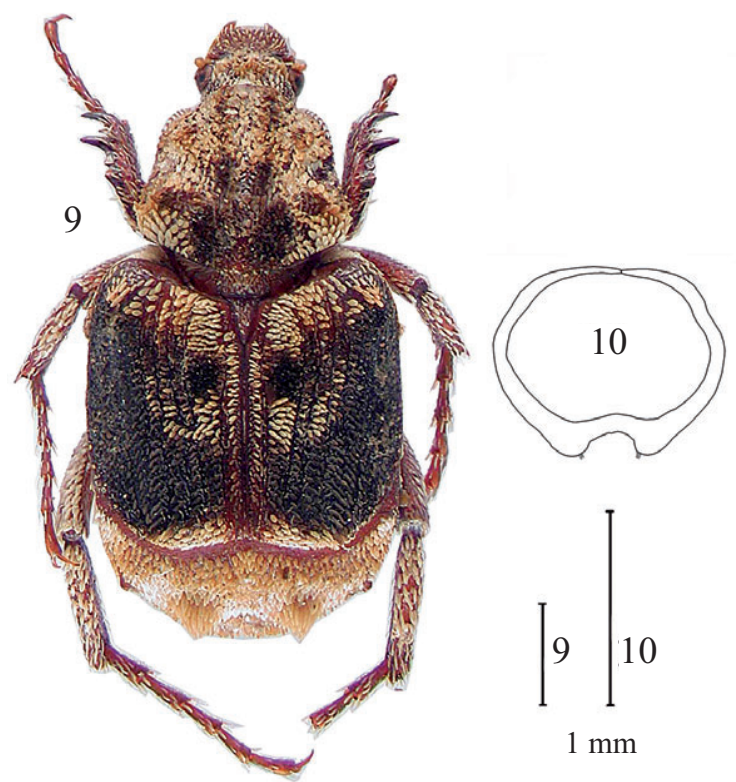

Figs. 9-10. Dasyvalgus hauseri sp.n. holotype male (SNMS); 9, habitus; 10, parameres, frontal view.
Etymology. This species is dedicated to C. Hauser, who collected the holotype.

\section{Dasyvalgus javus sp. n. (Figs. 11,12)}

TYPE SERIES. HT $\precsim$ ZFMK, Indonesia. Java, 1904.

HolOTYPE DESCRIPTION. Length $6.2 \mathrm{~mm}$, maximum width $4.0 \mathrm{~mm}$. Body black. Head matt, covered with small, shallow, circular punctures; frons covered with thick, testaceous, recumbent scales that form large scale tufts in interocular area; clypeus anteriorly sinuate, suctorial brush very long. Pronotum anteriorly narrowed, distinctly crenate at sinuated sides, hind angles obtuse; posterior border centrally curved towards scutellum; carina parallel, interrupted beyond pronotal midpoint by tuft of testaceous scales; base with four testaceous scale tufts; lateral small carinae obsolete, covered with small tuft of testaceous scales; central small carina obsolete; most of pronotal surface covered with scattered, recumbent testaceous scales. Scutellum short, triangular, slightly rounded at apex, covered with small, erect, testaceous scales. Elytra slightly shiny, covered with raised and locally recumbent, small, testaceous scales not forming a definite pattern, but with rounded vaguely

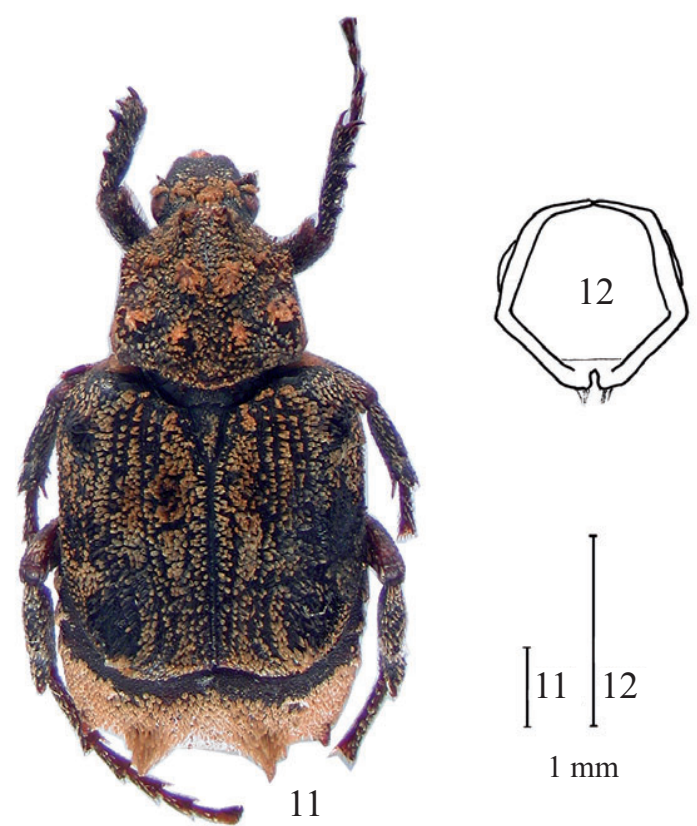

Figs. 11-12. Dasyvalgus javus sp.n. holotype male (ZFMK); 11, habitus; 12 , parameres, frontal view. 
blackish spot at center of disk; humeral umbones with black scale tuft; anteapical umbones with testaceous scale tuft. Propygidium covered with small, recumbent, testaceous scales, without definite pattern; hind border with two noticeable testaceous scale tufts; spiracles elevated and slightly pointed. Pygidium slightly laterally compressed close to the apex, covered with small, recumbent, testaceous scales; apex with testaceous, short scale tuft. Protibiae with five external teeth: first, second and fifth pointed, third and fourth shorter and rounded.

Meso- and metatibiae flat and centrally enlarged, with noticeable central tooth, covered with scattered, small, recumbent, testaceous scales; first metarsomere twice as long as second.

Diagnosis. Dasyvalgus javus can be distinguished by the following combination of characters: colour of the scale tufts; pronotal hind corner shape; shape of the external protibial denticles; relative length of the first and second metatarsal joints. The parameral shape is also very distinctive.

REMARKs. The female is unknown.

Distribution. Java, without precise locality.

Dasyvalgus frenzeli sp. n. (Figs. 13,16)

TYPE SERIEs. HT ð̊, NMER, Vietman, Hai Pong, Insel Thien Cung, 16-VII-2004, Dirk Frenzel legit.

HOLOTYPE DESCRIPTION. Length $5.8 \mathrm{~mm}$, width 3.4 $\mathrm{mm}$. Body dark brown. Head shiny, clypeus glabrous, covered with round, shallow, large, umbilicate punctures; frons covered with thick, whitish, recumbent scales forming three small scale tufts in interocular area; clypeus anteriorly sinuated, suctorial brush very long. Pronotum anteriorly narrower, distinctly crenate on sinuated sides; hind angles obtuse; posterior border centrally curved toward scutellum; carinae parallel, each interrupted near middle of pronotal length by a black scale tuft; base with four tufts of scales: external two whitish, inner two black; lateral and central small carinae obsolete, without any scale tufts; most of pronotal surface covered with thick, recumbent, oval whitish scales. Scutellum short, triangular, slightly rounded at apex, covered with small, recumbent, scattered whitish scales. Elytra slightly shiny, covered with recumbent whitish scales; with anterior band in juxtascutellar area covered with whitish, recumbent small scales; umbones (humeral and anteapical) each covered with tuft of scales, internally whitish, externally black; sutural and first interstriae covered with longitudinal band of thick, recumbent, oval whitish scales, with black spot at center. Propygidium covered with small, recumbent, whitish scales forming two noticeable scale tufts at hind border. Propygidium with spiracles elevated; point truncate. Pygidium slightly laterally compressed close to apex, covered with small, recumbent, oval whitish scales; apex with whitish, short scale tuft. Protibiae with five external teeth: first to third long and pointed, fourth and fifth small and pointed. Meso- and metatibiae centrally enlarged, with noticeable central tooth, covered with scattered, small, recumbent whitish scales; first metarsomere about 1.6 times as long as second.

REMARKS. The female is unknown.

Distribution. The HT comes from North Vietnam.

Diagnosis. Dasyvalgus frenzeri shows a parameral shape very close to that of $D$. formosanus Moser, 1915 (from Taiwan) and D. laligantii (Fairmaire, 1888) (from Hong Kong to northern Vietnam). D. frenzeri can be distinguished from the latter two species by its propygidial tufts of white scales, while the correspon-

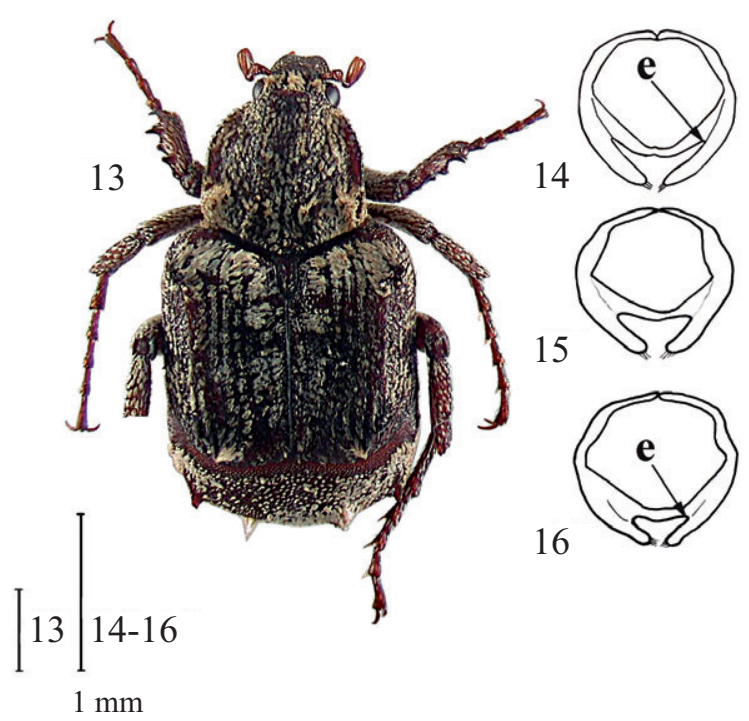

Figs. 13-16. Dasyvalgus frenzeli sp.n. holotype male (NMER); 13, habitus; 14, parameres, frontal view. Dasyvalgus formosanus Moser, 1915; 15, parameres, frontal view. Dasyvalgus laligantii (Fairmaire, 1888); 16, parameres, frontal view. (Note the different internal cavity depth (e) that distinguishes the parameres of $D$. frenzeli from those of $D$. formosanus). 
ding scale tufts are black in males D. laligantii and testaceous in males $D$. formosanus. A second important pygidial character in the latter two species is an area close to each dorsal corner, which is covered with scattered, erect, bristle-like, scales. The parameral shape is also distinctive.

\section{Dasyvalgus malayensis sp. n. (Figs. 17,18)}

TYPE SERIES. HT ô NHM, Malaysia, Kedah Peak, 29III-1928, 3950 feet, M. Pendlebury legit. PT's: 1ठ ERC, same data as the HT but 9-III-1928, 3300-3950 feet; 10 NHM, same data as the HT, but 25-III-1928; $1 \delta^{\top} \mathrm{NHM}$, same data as the HT but 20-II-1928, 33003600 feet, H.T.Pagdim legit.

HOLOTYPE DESCRIPTION. Length $7.8 \mathrm{~mm}$, maximum width $5.4 \mathrm{~mm}$. Body black. Head slightly shiny, covered with large, shallow, circular punctures, denser on occiput, scattered on clypeus; frons covered with thick, brown, recumbent scales, larger in interocular area; clypeus anteriorly sinuated, suctorial brush very long. Pronotum anteriorly narrower, noticeably cre-

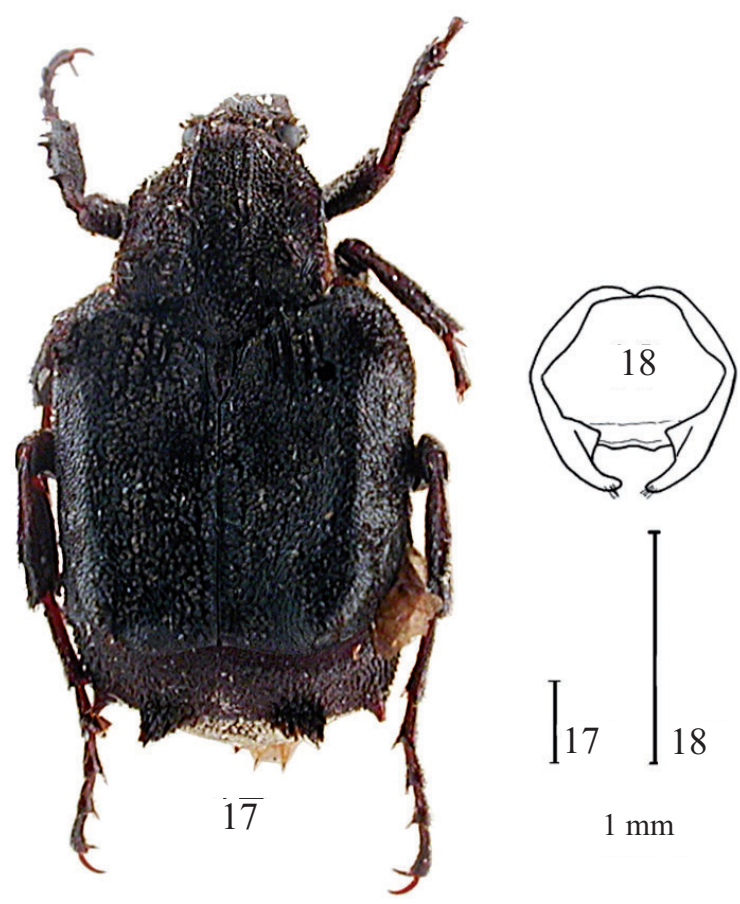

Figs. 17-18. Dasyvalgus malayensis sp. n. holotype male (NHM); 17, habitus; 18, parameres, frontal view. nate at sinuated sides; hind angles prominent and mostly glabrous; posterior border curved towards the scutellum; carinae parallel, each interrupted after pronotal midpoint by black scale tufts; base with four blackish tufts; lateral and central small carinae not present; most of pronotal surface shagreened and covered with dense, erect, small brown scales. Scutellum short, triangular, slightly rounded at apex, covered with small, erect, rounded, brownish scales. Elytra slightly shiny, covered with raised and locally recumbent, small, rounded, black, brown or testaceous scales not forming a definite pattern, but with rounded black area at center of disk; anteapical umbones covered with black scale tuft. Propygidium covered with small, rounded, recumbent testaceous scales, without definite pattern; hind border with two big scale tufts of erect, long black scales; spiracles elevated and pointed. Pygidium slightly laterally compressed below middle, covered with small, recumbent, rounded, testaceous scales; apex with divided scale tuft of long, testaceous scales. Protibiae with five external teeth: first three and fifth pointed, fourth rounded, first and second closer to each other than second is to third. Meso- and metatibiae flat and enlarged, without noticeable central tooth, covered with scattered, sometimes bristleslike, erect blackish scales; first metarsomere about twice as long as second.

TYPE SERIES VARIABILITY. All the specimens of the type series are similar.

REMARKS. The female is unknown.

DiAGNOSIS. This is a large species, well characterized by the pronotal angles, and the meso- and metatibial shapes. The parameral shape is distinctive too.

Distribution. Malaysian Peninsula.

Dasyvalgus pusillum sp. n. (Figs. 19,20)

TYPE SERIES. HT $\partial$, NHM, Malaysia, Sabah, Mt. TrusMadi, 20-II-2005, local collectors. 2 PT: 1 ô, ERC, same data as the HT; 10 WBWC, same data as the HT but $20-$ II-2008.

Holotype DESCRIPTION. Length $2.5 \mathrm{~mm}$, width 1.4 $\mathrm{mm}$. Body very small, dark brown. Head shiny, clypeus glabrous, covered with round, shallow, large, umbilicate punctures, sometimes with testaceous, small, erect bristles-like scales; frons covered with thick, testaceous, scattered scales that do not form small scale tufts in interocular area; clypeus anteriorly sinuate, suctorial brush very long. Pronotum anteriorly 
narrower, noticeably crenate at sinuated sides; hind angles obtuse; posterior border centrally curved towards the scutellum; carinae parallel, rounded; lateral and central small carinae obsolete; pronotal surface covered with thick, scattered, recumbent scales, posteriorly with scales erect and forming four very small basal scale tufts. Scutellum short, triangular, slightly rounded at apex, glabrous. Elytra shiny, covered with recumbent, very scattered, testaceous scales not forming a definite pattern, lacking scale tufts. Propygidium shiny, covered with large umbilicate, thick punctures, centre of some punctures with small, erect, bristleslike testaceous scales; only traces of hind border scale tufts present. Pygidium shiny, covered with same umbilicate punctuation as propygidium; with even more scattered erect, testaceous scales; apex continuously rounded, without apical scale tuft; discal surface impressed, close to anterior angles. Protibiae with five external teeth: first and third long and pointed, second very small and obsolete, fourth and fifth small and pointed. Meso- and metatibiae centrally enlarged, with noticeable central tooth, covered with scattered, small,
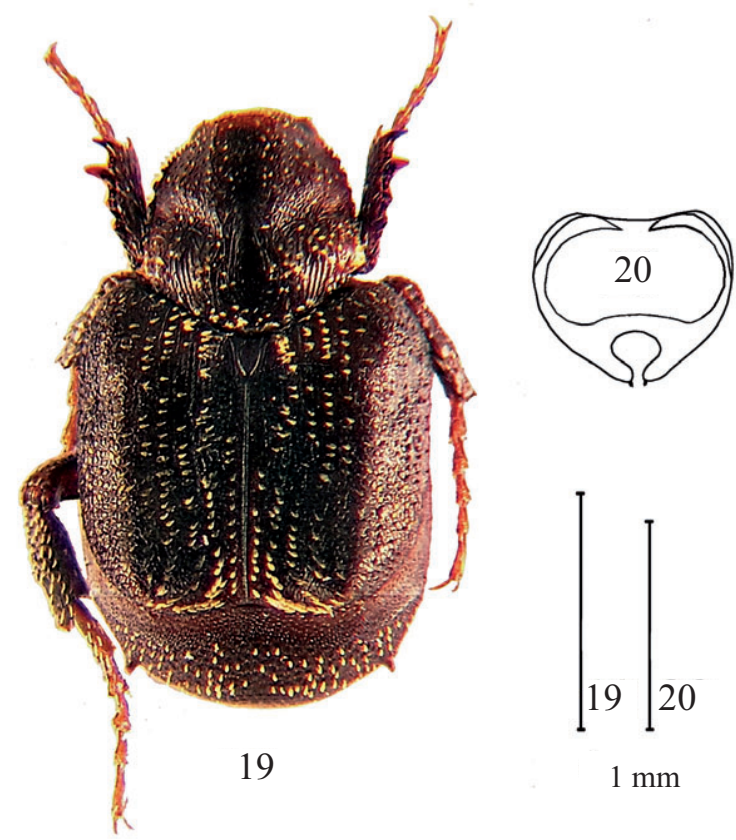

Figs.19-20. Dasyvalgus pusillum sp. n. holotype male (NHM); 19, habitus; 20, parameres, front view. semi-erect, testaceous scales; first metarsomere about 1.4-1.5 times length of second.

TYPE SERIES VARIABILITY. The two paratypes are similar to the holotype. However, one has the propygidium and pygidium brown instead of dark brown.

Remarks. The female is unknown.

Distribution. The entire type series is from Sabah.

Diagnosis. The only other very small Dasyvalgus known to inhabit Malaysia and Indonesia is $D$. pusio (Kolbe, 1904). This species may be distinguished from D. pusillum by its protibia having only four teeth, lacking the second tooth completely. The parameral shape is very distinctive as well. Due to the absence of scale tufts on pronotum, elytra and propygidium this new species belongs to the subgenus Spilovalgus (Ricchiardi, 1994). D. pusillum can be distinguished from the other Spilovalgus by the brown color instead of black, lack of a white tomentum spot of white scales on elytral disc and parameres shape (frontal view).

\section{Dasyvalgus rugosus sp.n. (Figs. 21,22)}

TYPE SERIES. HT $\widehat{\jmath}$ NMER, Chine, Yunnan (without precise data).

Holotype description. Length $5.4 \mathrm{~mm}$, width $3.7 \mathrm{~mm}$. Body completely black. Head slightly shiny, covered with shallow, large, confluent puntures. Clypeus anteriorly sinuate, suctorial brush very long. Pronotum very rugose, anteriorly narrower, noticeably crenate at sinuated sides; hind angles obtuse; posterior border centrally curved towards scutellum; carinae outwardly arched, sharp, extending as far as two-thirds of pronotum length; central small carina very noticeable, sharp; lateral carinae umbone-like; with another umbone-like elevation situated close to each posterior corner; discal surface very rugose, mostly glabrous but with black scale tuft at two-thirds of carinae and another identical scale tuft behind each carina, situated just before hind border. Scutellum short, triangular, apically rounded, glabrous. Elytra slightly shiny, mostly glabrous, but anterior border covered with band of straight, erect, dark testaceous scales; center of the disc with vague rounded spot of small, straight, erect black scales; scattered, straight, recumbent whitish scales around the black spot some reaching anteapical umbone; surface covered with recumbent, very scattered, testaceous, small scales not forming definite pattern; black scales at center of disk forming small sub-circular area; with very small and slightly noticeable black scale tufts on both in- 
trahumeral and anteapical umbones. Propygidium black, opaque, covered with round, thick, punctures and scattered, erect, straight, dark testaceous scales forming two noticeable scale tufts on posterior border. Pygidium black, opaque, covered with round, thick, punctures and scattered, erect, straight, dark testaceous scales; apex completely rounded, without scale brush or tuft. Protibiae with five external teeth: first three long and pointed, third largest, fourth and fifth smaller and pointed. Mesoand metatibiae centrally enlarged, with noticeable central tooth, and some scattered, long, erect, whitish scales; first metarsomere about twice as long as second. Abdomen black, almost glabrous, covered with round, shallow, large punctures.

DistRiBUTION. The holotype has been collected in Yunnan, but no further data area available.

REMARKS. The female is unknown.

Diagnosis. D. rugosus can be easily recognized by its very rugose pronotum, erect, scattered, dark testaceous scales on pygidium and propygidium, and by the parameral shape.
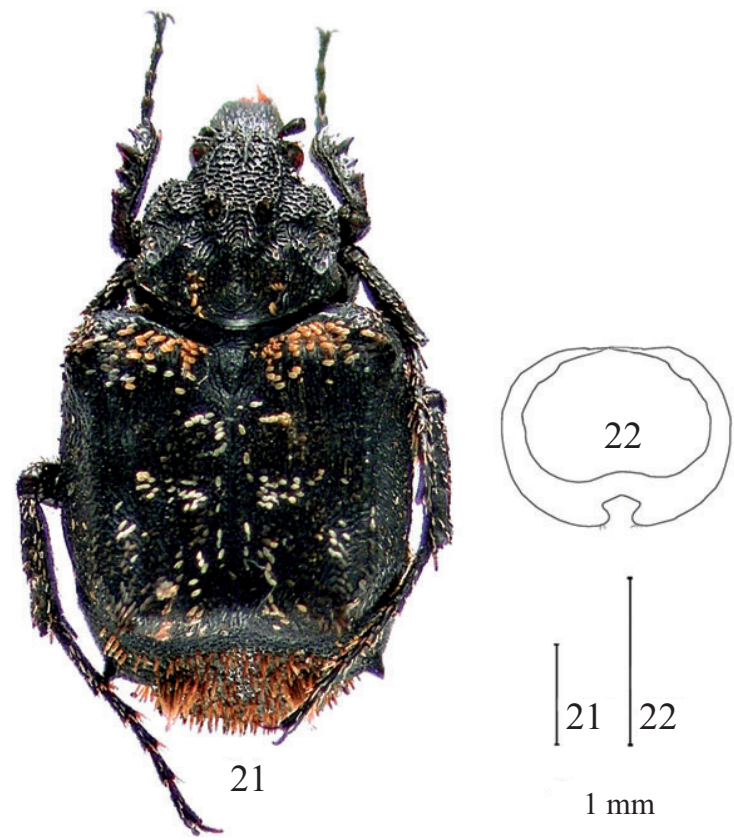

Figs. 21-22. Dasyvalgus rugosus sp. n. holotype male (NMER); 21, habitus; 22, parameres, frontal view.
Dasyvalgus trusmadii sp. n. (Figs. 23,24)

TYPE SERIES. HT $\partial$, NHM, Malaysia, Sabah, Mt. TrusMadi, 20-II-2005, local collectors. 17 PT's: $\widehat{\partial} \widehat{\partial}$, ERC 32 oै ${ }^{2} \mathrm{WBWC}$, same data as the HT.

HOLOTYPE DESCRIPTION. Length $5.0 \mathrm{~mm}$, width $3.0 \mathrm{~mm}$. Body small, mostly black dorsally. Head slightly shiny, covered with round, shallow, large, umbilicate puntures, some with testaceous, small, erect scale; clypeus anteriorly sinuate, suctorial brush very long. Pronotum anteriouly narrower, noticeably crenate at sinuated sides; hind angles obtuse; posterior border centrally curved towards scutellum; carinae parallel, rouded. Lateral and central small carinae obsolete; pronotal surface glabrous except for six small black scale tufts, noticeable in lateral view, : four in line close to posterior border, two in front of central two. Scutellum short, triangular, slightly rounded at apex, glabrous. Elytra shiny, covered with recumbent, very scattered, testaceous, small scales not forming definite pattern; center of disk with small sub-circular area of white scales; very small and slightly noticeable black scale tufts on both

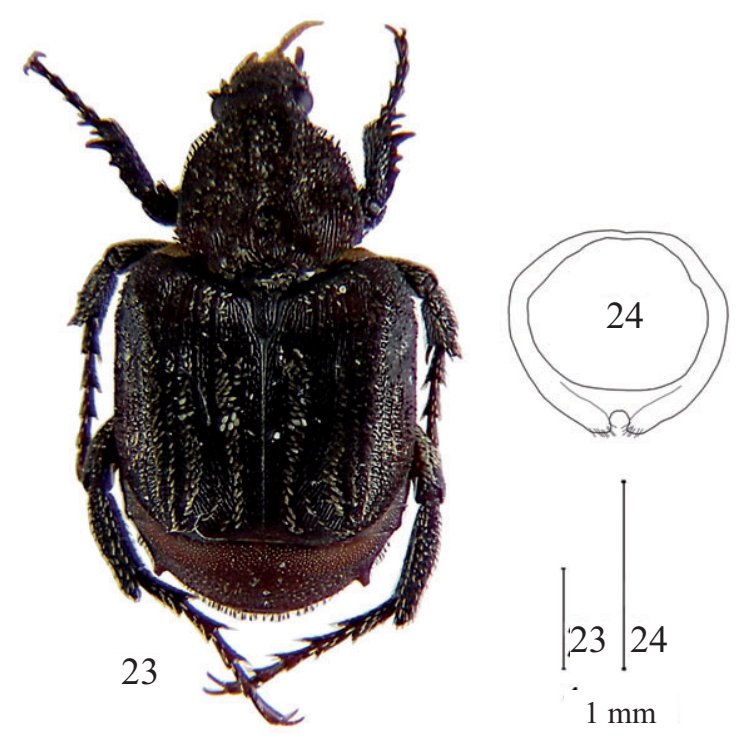

Figs. 23-24. Dasyvalgus trusmadii sp. n. holotype male (NHM); 23, habitus; 24, parameres, frontal view. 
intrahumeral and anteapical umbones. Propygidium reddish brown, slightly shiny, covered with large umbilicate, thick punctuation, rarely with one small, erected, testaceous scale at centre of some of thye point. Only traces of black scale tufts on hind border. Pygidium reddish brown, slightly shiny, covered with large umbilicate, thick punctuation, some punctures with small, erect, bristles-like testaceous scales at the centre; apex continuously rounded, without apical scale tufts. Protibiae with five external teeth: first and third long and pointed, second slightly smaller and pointed, fourth small and pointed, fifth larger than fourth and rounded. Meso- and metatibiae centrally enlarged, with noticeable central tooth, with some scattered, long, erect, testaceous scales and covered with slightly noticeable, recumbent, testaceous scales. First metarsomere about 1.1-1.2 times as long as second. Abdomen reddish brown, dorsally blackish, sternites centrally covered with thick, recumbent, testaceous scales.

TYPE SERIES VARIABILITY. Some paratypes have the propygidium, pygidium and sternites almost black, instead of reddish brown. Some paratypes lack most of pronotal black scale tufts.

REMARKS. The female is unknown.

Distribution. The entire type series comes from Mt. Trus-Madi, Sabah.

Diagnosis. D. trusmadii is a small, black species recognized by propygidium and pygidium glabrous or with very scattered, small, bristles-like testaceous scales. The propygidium scale tufts at the posterior border are present in traces only. The parameral shapes are distinctive.

\section{Dasyvalgus yoshikazui nom. n.}

Discussion. Dasyvalgus nigerrimus Miyake, 1993 is a primary junior homonym of $D$. nigerrimus Moser,
1904, as the two species are congeneric. I wrote to Dr. Yoshikazu Miyake years ago about this nomenclatural problem and he responded that he would correct the problem by assigning a new name to the species. As he has not published a new name, I hereby propose as nomem novum for the Miyake species D. yoshikazui in honor of Dr. Miyake, since "miyakei" is already occupied by D. miyakei Ricchiardi, 1995. Miyake (1993) based his description on two males from Thailand (Chiang Mai Province). The species is also present in North Vietnam, as a single male from that country deposited in my collection shows. Its data are: Tonkin, Thai Nien, Banks of fleuve Rouge, 1924, legit H. Stevens.

Valgus arabicus (Nonfried, 1895): new junior synonim of $V$. seticollis Beauvois, 1807.

TYPE SERIES. LT + , MNHUB, Arabia (Nonfried (1895, p. 295 - 296) does not state how many specimens were studied. Furthermore he reported as the new species locality: "El Sâna, Arabien", but on the LT label only "Arabia" is reported. The LT female here designated corresponds well with the original description of the species).

Discussion. This species was described by Nonfried (1895) from a specimen labelled "El Sâna, Arabien". Nonfried was not aware that the specimen was a female belonging to a North American species, Valgus seticollis Beauvois, 1807. The presence of a Valgina on the Arabian Peninsula is strange given the climate, and the species has not been collected since the description. In fact no Valgini are present in the area, nor in Somalia or Djibouti on the western side of the Red Sea. Probably the specimen was mislabelled, or, if really collected in Yemen, may have been transported with wood imported from the United States. 


\section{REFERENCES}

ARrow G.J., 1944 - The beetles of the Lamellicorn subfamily Valginae, with a synopsis of the genera and descriptions of some new species. Transactions Royal Entomological Society London. 94, part 2, 225-246.

Kolbe H.J., 1904 - Gattungen und Arten der Valgiden von Sumatra und Borneo. Entomologische Zeitung, Heft I, $1904:$ 3-57.

KraAtZ G., 1883 - Ueber di Gattung Valgus un eine Anzahl neuer Arten derselben. Deutsche Entomologische Zeitschrift. XXVII, Heft II.

MiYAKE Y., 1993 - New or little known species of subfamily Valginae from Indochina. Lamellicornia 9: 21-30.

Nonfried A.F., 1895 - Coleoptera nova exotica. Berliner Entomologische Zeitschrift Band XL, Heft III: 295-296.

RicCHIARDi E., 1992 - On the Valginae genus Heterovalgus with description of three new species. Bollettino della Società Entomologica Italiana, 124 (2): 115-120.

RICCHIARDI E., 2001 - Revisione tassonomica del genere Oreoderus Burmeister, 1842, con descrizione di undici nuove specie (Coleoptera Cetoniidae, Valginae). Annali del Museo Civico di Storia Naturale "G. Doria", Genova Vol. XCIII : $507-$ 557.

Indirizzo dell'autore:

Enrico Ricchiardi, corso Tassoni 79/4, 10143 Torino, Italia. E-mail: alericor@fastwebnet.it 